\title{
NFUD Symposium 2014 i Ålesund
}

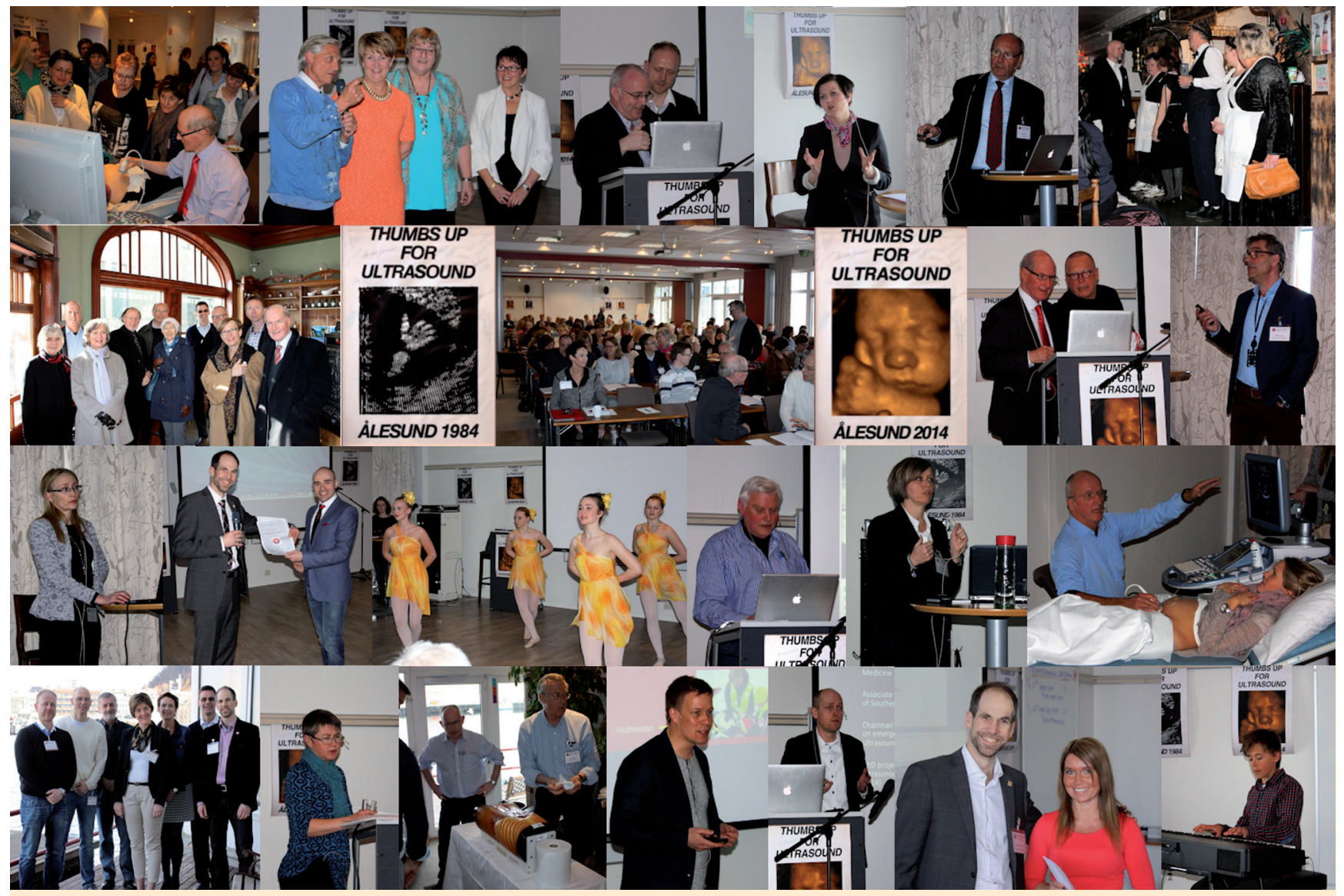

Fig. 1 Inntrykk fra NFUD symposium 2014 i Ålesund.

I år ble NFUD symposiet avholdt 2. - 4. april i Ålesund. Symposiet markerte 30 år siden NFUD møtet i 1984 "Thumbs up for Ultrasound", som var grunnleggende for dagens tilbud om rutineultralyd rundt uke 18 til alle gravide kvinner i Norge.

Stuart Campbell, B. Joachim Hackelöer, Bjørn Angelsen, Sturla Eik-Nes og Svein Ødegård, de fleste av dem deltok også for 30 år siden, ga et utfyllende overblikk over ultralydens utvikling de siste 30 år.
Jim Connolly og Christian B. Laursen presenterte hhv. "point of care" ultralyd og helkroppsultralyd i akuttmottaket. Her har ultralyddiagnostikken vist seg å være en forholdsvis lett lærbar og overlegen metode til å stille rette diagnosen og dermed tilføre pasienten målrettet behandling tidligere enn ved bruk av tradisjonell diagnostikk. Direkte etterpå kunne deltakerne fordype det nettopp hørte med praktiske øvelser på en treningsmodell under veiledning.
På muskelskjelettfeltet stilte Canh Le Nygaard, Tomas Skei, Herlof Harstad, Hilde Berner Hammer og Lene Terslev opp som 


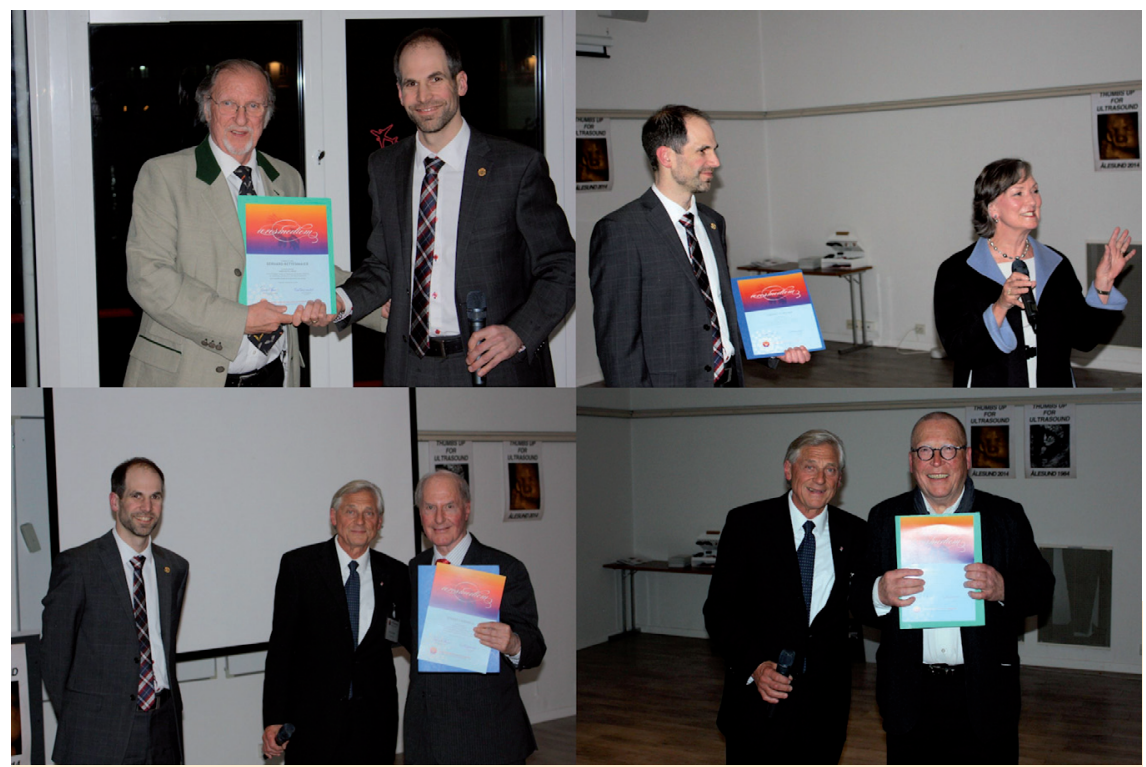

Fig. 2 Nye æresmedlemmer i NFUD: Svein Ødegård tar imot diplomet for Gerhard Rettenmaier (øverst til venstre), styreleder Roald Havre og Lindsey D. Allan (øverst til høyre), Roald Havre, Sturla Eik-Nes og Stuart Campell (nederst til venstre) og Sturla Eik-Nes og Joachim B. Hackelöer (nederst til høyre).

både forelesere og veiledere ved praktiske øvelser.

Karel Maršál, Lindsey D. Allan og HarmGerd Blaas hadde innlegg om hhv. Doppler, føtal ekkokardiografi og skjelettpatologi i forbindelse med prenatal ultralyd. Gunn Hulleberg avrundet sesjonen med en utfyllende oversikt over postnatal behandling av skjelettpatologi.

Ulrike Waje-Andreassen, Lars Thomassen, Ingegerd Aagenes og Kim Nylund hadde fokus på ultralyd av karsystemet ved hhv. halskar, trombolyse ved hjerneinfarkt, intracerebrale blødninger hos premature og i tarmsystemet.

Morten Glasø og Claudia Heien sine foredrag dreide seg om ultralyd på fastlegekontor, og ble basis for en livlig diskusjon rundt dette evnet.

Rune Hansen, Spiros Kotoupolis og Georg Dimcevski ga et veldig interessant innblikk i terapeutisk ultralyd og nanoteknologi i forbindelse med blant annet målrettet og selektiv applikasjon av medikamenter.

Strukturert ultralydutdanning og sertifisering er et svært omdiskutert og tiltagende viktig tema, som ble belyst av Lene
Terslev, Bård S. Rannestad, Kari Utne, Odd Helge Gilja og B. Joachim Hackelöer.

Gerhard Rettenmaier, Stuart Campbell, B. Joachim Hackelöer og Lindsey D. Allan ble utnevnt som æresmedlemmer for sine fortjenester i forbindelse med utvikling av gastroenterologisk og obstetrisk ultralyd $\mathrm{i}$ Norge.

Eva Johanne Leknes Jensen fikk prisen for beste frie foredrag i form av 10000 NOK for sitt innlegg , Venstresidig isomerisme hos foster".

NFUDs forskningsstipend på 10000 NOK ble tildelt Andreas P. Diamantopoulus for sitt prosjekt „Contrast Enhanced Ultrasound as a marker of disease activity in large vessel vasculitis-giant cell arteritis“.

Med 152 registrerte deltakere var årets møte svært godt besøkt. Ut ifra tilbakemeldingene styret fikk kan møtet anses som både faglig og sosialt vellykket.

Flere bilder finnes på NFUDs nettside http://www.nfud.no/. En mer utradisjonell presentasjon av bildene fra symposiet finnes på YouTube http://www.youtube. com/watch?v=gHvywQzwQXQ. 